\section{Problems and solutions encountered in psychological counseling and guidance services: A metasynthesis study}

Psikolojik danışma ve rehberlik servisinde karşılaşılan sorunlar ve çözüm önerileri: Bir metasentez çalışması

\author{
Serkan Cengiz ${ }^{1}$ \\ Şeyma Bilgiz Öztürk ${ }^{2}$
}

\begin{abstract}
In this research, on guidance issues in the literature in Turkey, examining realized that qualitative article as a whole, the counselors, their problems bring problems rather than their guidance and is intended to reveal to synthesize suggestions to solve these problems. For this purpose, guidance service problems, school psychological counselor problems, guidance services were written to Web of Science, Ulakbim, Dergi Park, Google Academic databases and the article was scanned. Articles dealing with counseling services and solutions were included in the research. What are the articles in depth guided by guidance services; Inadequacy of physical provision and facilities, problems in the preparation and presentation of research, the problem of prejudice towards the school psychological counselor and services and problem themes related to guidance services policies. Later sub-problems related to these themes were created and solutions to these problems were classified from the articles included in the study.
\end{abstract}

\footnotetext{
1 Uzman Psikolojik Danışman, Rehberlik ve Araştrma Merkezi, stkn cngz 25@, hotmail.com (D) Orcid ID: 0000-0001-9070-6338

2 Araştırma Görevlisi., Atatürk Üniversitesi, Kazım Karabekir Eğitim Fakültesi, Eğitim Bilimleri Bölümü, seyma.bilgiz@atauni.edu.tr (D) Orcid ID: 0000-0002-6506-7236
}

\section{Özet}

$\mathrm{Bu}$ araştırmada, alan yazında rehberlik hizmetleri sorunları konusunda, Türkiye' de gerçekleştirilmiş nitel makale çalışmalarını bir bütün halinde inceleyip, psikolojik danışmanların, rehberlik hizmetlerini yerine getirme açısından yaşadıkları sorunları ve bu sorunların çözümüne yönelik önerileri sentezleyerek ortaya çıkarmak amaçlanmıştır. Bu amaç doğrultusunda Web of Science, Ulakbim, Dergi Park, Google Akademik veri tabanlarına rehberlik hizmetleri sorunlar, okul psikolojik danışman sorunlar, rehberlik hizmetleri yazılarak makale çalışmaları taranmıştur. Rehberlik hizmetlerinin sorunları ve çözüm yollarını ele alan makaleler araştırmaya dahil edilmiştir. Makalelerin derinlemesine incelenmesi sonucunda rehberlik hizmetlerinin yürütülmesinde; fiziki koşullar ve imkanların yetersizliği, çalışmaların hazırlanması ve sunumunda yaşanan sorunlar, okul psikolojik danışmanının görevleri ve hizmetlere yönelik önyarg1 sorunu, rehberlik hizmetleri politikalarına ilişkin sorun temaları oluşturulmuştur. Daha sonra bu temalara ait alt 
Cengiz, S., \& Bilgiz Öztürk, Ș. (2020). Psikolojik danışma ve rehberlik servisinde karșlașılan sorunlar ve çözüm önerileri: Bir metasentez çalışması. Journal of Human Sciences, 17(4), 1069-1082. doi:10.14687/ihs.v17i4.6054

Keywords: Guidance services, guidance services problems, school counselor problems.

(Extended English summary is at the end of this document) sorunlar oluşturularak, çalışmaya dahil edilen makalelerden bu sorunların çözüm yolları sınıflandırılmıştır.

Anahtar Kelimeler: Rehberlik hizmetleri, rehberlik hizmetleri sorunları, okul psikolojik danışman sorunları.

\section{Giriş}

Amerikan Psikoloji Derneği (APA, 2006) profesyonel anlamda psikolojik danışma ve rehberliği; psikoloji, ruh sağlığı ve gelişim ilkelerinin farklı ve profesyonel müdahale stratejileri aracılığıyla, bireyin kişisel, mesleki ve ruhsal anlamda sorunlarını ele alan uygulamalar olarak tanımlamaktadır. Rehberlik ve psikolojik danışma, okullarda öğrencilere yönelik mesleki, eğitsel ve kişisel sorunlarına yönelik çözüm önerileri sunan, bireyin çevresinde var olan imkanları tanımasını sağlayarak kendini gerçekleştirmesini amaçlayan sistemli, profesyonel yardım etme sürecidir (İkiz, 2016; Hohenshil, Amundson ve Niles, 2015). Türkiye'de rehberlik kavramı kullanım1 ve yaygınlaşması 1950'li yıllarda başlamıştır (Poyraz, 2007). Milli Ë̆itim Bakanlı̆̆1 1976 yılında ortaöğretim kurumları dışındaki kurumlarda rehberlik hizmetlerini zorunlu hale getirmiştir. 1983 yllında ise okullarda rehberlik hizmetlerini yerine getirecek psikolojik danışmanların istihdamına başlanmıştır. 2005-2006'lı yıllara kadar temel alınan geleneksel rehberlik hizmetleri anlayışı yerini gelişimsel rehberlik anlayışına bırakmıştır. Çünkü verilen hizmetlerin öğrencilere olan katkısı ve okul psikolojik danışmanların neler yaptığını görme gereği duyulmuştur (Nazlı, 2014). Bu yaklaşımla birlikte rehberlik hizmetlerinin merkezine öğrenciler alınmış olup, her okul kendi tür ve ihtiyacına göre programda düzenlemeler yapmıştır. Programın değerlendirilmesi ise üç boyuttan oluşmaktadır. Bunlardan birisi de uygulanan rehberlik hizmetlerinin etki ve verimliliğinin okul psikolojik danışmanı tarafından değerlendirilmesidir (Gysbers ve Henderson, 2014). Kişisel, mesleki ve eğitsel alanlarda verilen bu hizmetlerin değerlendirilme noktasında psikolojik danışmanlar bazı sorunlarla karşılaştıklarını belirtmiştir (Yeşilyaprak, 2012; Özaydın, Şahin ve Siyez, 2019). Yapılan araştırmalar incelendiğinde; psikolojik danışmanların hizmetleri yerine getirmede sıklıkla; okullardaki fiziki imkânsızlık (Akpınar ve Bengisoy, 2017; Pişkin, 2006), görev tanımındaki belirsizlik (Toprakçı ve Altunay, 2014), alan dışı atamalar (Tuzgöl Dost ve Keklik, 2012; Yıldız ve Türk, 2018) çalışmalarda iş birliği eksikliği (Çokamay, Kapçı ve Sever, 2017; Korkut Owen ve Owen, 2008; Hamamc1, Murat ve Çoban, 2004) sorunlarıyla karşılaştığ1 görülmektedir. Eğitim sisteminin önemli bir parçası olan rehberlik hizmetlerinin yürütülmesinde karşılaşılan bu tip sorunlar öğrenciler başta olmak üzere, veli ve diğer öğretmenlerin süreçteki hizmetlerden yararlanmamasına ve okulda ortak bir rehberlik hizmeti anlayışı oluşmamasına neden olmaktadır (Günay ve Özbilen, 2014; Karaca ve İkiz, 2010). Yaşanan bu sorunlara çözüm getirilmesi hizmetlerin sürekliliği ve işlevselliği için önemlidir. Çünkü okul ruh sağlığ1 hizmetlerinin aksatılmadan yürütülmesi, mevcut sorunların çözümünden geçmektedir (Selen, 2008). Alanyazında yapılan araştırmalarda rehberlik hizmetlerini yerine getirmede psikolojik danışmanların yaşadıkları çoğu sorunu gün yüzüne çıarmaktadır. $\mathrm{Bu}$ araştırmada da yaşanan sorunların meta sentez yöntemi ile analiz edilerek yaşanan sorunların derlenmesi ve bu sorunlara yönelik çözüm önerilerinin sunulması oldukça önemli olduğu düşünülmektedir. Ayrıca okullarda okul psikolojik danışma ve rehberlik hizmetleri takımının doğal üyesi olan okul müdürü, sınıf rehber öğretmeni, öğrenci, resmi sorumlu paydaşlara rehberlik hizmetlerinin aksayan yönlerini göstermek ve sorunlara çözüm yolları sunmak, başta rehberlik hizmetlerine olan yanlış düşünceler olmak üzere diğer birçok sorunda farkındalığ1 artıracağ1 düşünülmektedir. 
Cengiz, S., \& Bilgiz Öztürk, Ș. (2020). Psikolojik danışma ve rehberlik servisinde karșlașılan sorunlar ve çözüm önerileri: Bir metasentez çalışması. Journal of Human Sciences, 17(4), 1069-1082. doi:10.14687/ihs.v17i4.6054

\section{Araştırmanın Amacı}

Bu meta-sentez araştırmasının amac1, alan yazında rehberlik hizmetleri sorunları konusunda, 'Türkiye' de gerçekleştirilmiş nitel makale çalışmalarını bir bütün halinde inceleyip, psikolojik danışmanların, rehberlik hizmetlerini yerine getirme açısından yaşadıkları sorunları ve bu sorunların çözümüne yönelik önerileri sentezleyerek ortaya çıkarmaktır. Bu amaç doğrultusunda aşağıdaki sorulara yanıt aranmıştır:

1-) Türkiye'de gerçekleştirilen makale çalışmalarında psikolojik danışmanların, psikolojik danışma ve rehberlik hizmetlerinin yürütülmesinde karşılaştıkları güçlükler nelerdir?

2-) Türkiye'de gerçekleştirilen makale çalışmalarında psikolojik danışmanların, psikolojik danışma ve rehberlik hizmetlerinin yürütülmesinde karşılaştıkları güçlüklere yönelik çözüm önerileri nelerdir?

\section{1. Araştırmanın Modeli}

\section{Yöntem}

Araştırma nitel araştırma yöntemlerinden metasentez araştırma modelinde gerçekleştirilmiş bir çalışmadır. Metasentez araştırmaları, belirli bir alanda gerçekleştirilen çalışmaların nitel bulgularının yorumlanması, değerlendirilmesi, yeni çıkarımlar yapılmayı sağlayan çalışmalardır (Glesne, 2014). Araştırmada da metasentez yöntemi kullanılarak, psikolojik danışmanların rehberlik hizmetlerine yönelik çalışmalarında yaşadıkları sorunlar ve bu sorunlara yönelik çözüm önerilerini ele alan nitel çalışmaların bulgu, sonuç ve tartışma kısımları sistematik bir şekilde bir araya getirilerek sorunlar ve çözümler üzerine sentezleme yapılmıştır.

\section{2. Verilerin Toplanması ve Analiz Süreci}

Araştırmada kullanılan verilere eğitim bilimleri alanında önemli çalışmaları barındıran; Web of Science, Google Akademik, Dergi Park ve Ulakbim veri tabanlarından, okul psikolojik danışmanı, okul rehberlik servisleri, rehberlik hizmetleri sorunları, rehberlik öğretmenleri sorun ve çözümleri anahtar kelimeleri yazılarak ulaşılmıştır. Bu süreçte incelenen makalelerde herhangi bir tarih kısıtlamasına gidilmemiş olup, geçmişte yaşanan sorunların günümüzdeki varlığı ve sürekliliğ̈inin incelenmesi amaçlanmıştır. Analize dahil edilecek çalışmalarda bildiriler ve tezler inceleme dışında tutulmuştur. Nitel çalışmalar anahtar kelimeler aracıllı̆̆ ile taranmış olup, seçime dahil edilme ve hariç tutma kriterleri, çalışmanın yazarları tarafindan önce ayrı ayrı incelenmiş, ardından araştırma kriterlerine uygun şekilde belirlenmiştir. Analize dahil edilme sürecinde ilk olarak ulaşılan çalışmaların, özet bölümleri incelenmiştir. Bu çalışmalardan erişime açık olan nitel çalışmalar incelenmiştir. Uygun bulunan çalışmaların başta bulgular bölümü olmak üzere, diğer bölümleri de sırası ile önce araştırmacılar tarafindan birbirlerinden bağımsız bir şekilde okunmuştur. Ardından araşturmacılar bir araya gelerek oluşturdukları temel ve alt sorunları değerlendirerek temel sorunlar ve alt sorunları oluşturmuşlardır. Her bir çalışmadan elde edilen bilgilerin doğru bir şekilde tanımlanmasına ve uygun şekilde başlıklara yerleştirilmesine dikkat edilmiştir. Ardından kullanılan her bir makaleye A1, A2, A3, A4, A5... şeklinde kodlar verilmiş olup, kodlanan bu çalışmaların yazarları, sorun ve çözüm önerilerinde kaç kez kullanıldığı da tablo 1'de belirtilmiştir.

Tablo 1. Sorun ve Çözüm Önerileri İçin Kullanilan Makaleler

\begin{tabular}{lll}
\hline Makale Kodu & Makale Yazarları & f \\
\hline A1 & Akpınar ve Bengisoy (2017) & 5 \\
\hline A2 & Arıcıŏlu ve Tagay (2010) & 5 \\
\hline A3 & Aydın (1988) & 2 \\
\hline A4 & Bakioğlu ve Gayık Asyalı (2005) & 4 \\
\hline A5 & Çil, Tokat, Türkan ve Doğan (2014) & 1 \\
\hline A6 & Çokamay, Kapçı ve Sever (2017) & 8 \\
\hline A7 & Doğan (1996) & 5 \\
\hline A8 & $\begin{array}{l}\text { Donat Bacığlu, Onat Kocabiyık ve Malkoç } \\
\text { (2017) }\end{array}$ & 2 \\
\hline
\end{tabular}


Cengiz, S., \& Bilgiz Öztürk, Ş. (2020). Psikolojik danışma ve rehberlik servisinde karşılaşılan sorunlar ve çözüm önerileri: Bir metasentez çalışması. Journal of Human Sciences, 17(4), 1069-1082. doi:10.14687/ihs.v17i4.6054

\begin{tabular}{lll}
\hline A9 & Güven (2009) & 2 \\
\hline A10 & Hatunoğlu ve Hatunoğlu (2006) & 2 \\
\hline A11 & Karaküçük (2010) & 2 \\
\hline A12 & Karataş ve Şahin Baltac1 (2013) & 11 \\
\hline A13 & Karataş ve Polat (2013) & 8 \\
\hline A14 & Kepçeoğlu (1987) & 2 \\
\hline A15 & Nuryüz, Dağyar veYeşiloğlu (2016) & 5 \\
\hline A16 & Okur (2009) & 2 \\
\hline A17 & Parmaksız ve Gök (2018) & 13 \\
\hline A18 & Tagay ve Savi Çakar (2017) & 13 \\
\hline A19 & Tan (1974) & 6 \\
\hline A20 & Terzi, Ergüner Tekinalp ve Leuwerke (2011) & 4 \\
\hline A21 & Toprakç1 ve Altunay (2014) & 8 \\
\hline A22 & Tuzgöl Dost ve Keklik (2012) & 5 \\
\hline A23 & Ünal ve Ünal (2010) & 2 \\
\hline A24 & Yeşilyaprak (2009) & 2 \\
\hline A25 & Yildı ve Türk (2018) & 1 \\
\hline
\end{tabular}

\section{Bulgular}

Bu bölümde psikolojik danışmanların okullarda en sık karşılaştığı sorunlar ve bu sorunlara yönelik çözümleri içeren makaleler incelenmiştir. Makalelerden yaşanan sorunlar incelenerek kavramsallaştırılmış, bu kavramlar kendi arasında düzenlenmiş ve sorunları açıklayabilecek temalar saptanmıştır. Elde edilen bulgular sonucunda, fiziki koşul ve imkanlardan kaynaklı sorunlar, çalışmaların hazırlanması ve sunumuna dair sorunlar, mesleki gelişim ve tecrübe eksikliğinden oluşan sorunlar, hizmetlere ve görev tanımına ilişkin önyarg1 sorunları, rehberlik hizmetleri politikalarından kaynaklı sorunlar olmak üzere beş temel sorun ortaya çıkmıştır. Daha sonra çalışmalardan faydalanarak belirlenen her bir temel sorun için kendi içerisinde anlamlı ve ilişkili olduğu düşünülen alt sorunlar oluşturulmuş ve bu alt sorunlara yönelik kaynaklardan elde edilen çözüm önerileri sınıflandırılmıştır.

\subsection{Fiziki Koşul ve İmkanlardan Kaynaklı Sorunlar ve Çözüm Önerilerine İlişkin Bulgular}

Okullarda rehberlik hizmetleri alan ve uygulamalarında psikolojik danışmanları etkileyecek etkenlerden birisi, okulların ve rehberlik odalarının sahip olduğu fiziksel şartlar ve imkanlardır. Bu noktada yaşanabilecek eksiklik veya sorunlar, psikolojik danışmanın yapacağı çalışmaları doğrudan veya dolaylı olarak olumsuz bir şekilde etkileyebilecektir. Tarama sonucunda elde edilen bilgiler doğrultusunda soruna ilişkin alt sorunlar ve çözüm önerileri Tablo 2'de sunulmuştur.

Tablo 2. Fiziki Koşul ve İmkanlardan Kaynaklı Alt Sorunlar ve Çözüm Önerileri İçin Kullanılan Makaleler

\begin{tabular}{|c|c|c|c|c|}
\hline Alt Sorun & Kaynak & Çözüm Önerileri & Kaynak & $\begin{array}{l}\text { İlgili } \\
\text { Paydaş }\end{array}$ \\
\hline $\begin{array}{l}\text { Rehberlik servisi } \\
\text { eksikliği }\end{array}$ & $\begin{array}{l}\text { A1, A19, A18 } \\
\text { A7, A21, A17 }\end{array}$ & Uygun bir mekan sağlanması & A17, A18, A19 & $\begin{array}{l}\text { Okul } \\
\text { Yönetimi }\end{array}$ \\
\hline \multirow[t]{2}{*}{$\begin{array}{l}\text { Donanim } \\
\text { eksikliği }\end{array}$} & $\begin{array}{l}\text { A1, A10, A7 } \\
\text { A4, A19, A11 } \\
\text { A8, A14, A21 }\end{array}$ & $\begin{array}{l}\text { Gerekli donanim malzemelerin } \\
\text { temin edilmesi }\end{array}$ & $\mathrm{A} 7, \mathrm{~A} 8$ & $\begin{array}{l}\text { Okul } \\
\text { Yönetimi, } \\
\text { MEB }\end{array}$ \\
\hline & A14 & $\begin{array}{l}\text { Bakanlığın okulların ihtiyaçlarını } \\
\text { gözetecek ilgili birim geliştirmesi }\end{array}$ & A14 & \\
\hline $\begin{array}{l}\text { Toplant1-sunum } \\
\text { odas1 eksikliği }\end{array}$ & A17, A18 & $\begin{array}{l}\text { Toplantı ve sunuma uygun } \\
\text { mekanlanın sağlanması }\end{array}$ & A17, A18 & $\begin{array}{l}\text { Okul } \\
\text { Yönetimi }\end{array}$ \\
\hline
\end{tabular}


Rehberlik servisi eksikliği: Tablo 2'de psikolojik danışmanların, hizmetleri yürütme esnasında kullanacakları hususi bir odanın bulunması gerektiğine yönelik ulaşılan çalışmalar yer almaktadır.

Çözüm önerileri: Sorunun çözümüne ilişkin yapılan çalışmalar tablo 2'de gösterilmiştir. Çalışmalarda okul idaresi tarafindan rehberlik hizmetlerinin yürütüleceği bir mekanın temin edilmesi gerektiği önerilmiştir.

Rehberlik servisinde donanım eksikliği (araç, gereç yetersizliği): Tablo 2'de rehberlik servislerinin donanım olarak (araç, gereç, malzeme) yeterli olmamasına ilişkin elde edilen çalışmalar kodlanmıştır.

Çözüm önerileri: Tablo 2'de donanım eksikliğine yönelik çözüm önerileri içeren araştırmalarda, rehberlik servislerinin vazgeçilmezi olan panoların ve diğer temel ihtiyaç malzemelerinin okul yönetimince temin edilmesi gerektiği ele alınmıştır.

Toplantı ve sunum odası eksikliği: Taranan araştırmalarda, okullarda rehberlik hizmetlerinin uygulama aşamasında kullanılacak uygun bir toplantı veya konferans salonunun eksikliği hizmetleri yürütmede sorun olarak görülmektedir.

Çözüm önerileri: Velilere ve öğrencilere yönelik olarak yapılacak çalışmalarda kullanılacak toplantı-sunum odalarının, okul müdürlerinin uygun bir oda temin etmesi ile çözülmesi önerilmiştir.

\section{2. Psikolojik Danışma ve Rehberlik Hizmetlerin Hazırlanması ve Sunumuna Dair} Sorunlar ve Çözüm Önerilerine İlişkin Bulgular

Rehberlik hizmetleri çalışmalarının hazırlanmasında psikolojik danışmanlar bazı sorunlarla karşılaşmaktadır. Soruna ilişkin kaynak tarama sonrası ilgili alt sorunlar ve çözüm yolları Tablo 3'te gösterilmiştir.

Tablo 3. Hizmetlerin Hazırlanması ve Sunumuna İlişkin Alt Sorunlar ve Çözüm Önerileri İçin Kullanılan Makaleler

\begin{tabular}{|c|c|c|c|c|}
\hline Alt Sorun & Kaynak & Çözüm Önerileri & Kaynak & İlgili Paydaş \\
\hline \multirow[t]{2}{*}{$\begin{array}{l}\text { Psikolojik } \\
\text { Danışman Eksikliği }\end{array}$} & $\begin{array}{l}\text { A1, A2, A10, A3, A4, } \\
\text { A13, A6, A9, A18 }\end{array}$ & $\begin{array}{l}\text { Psikolojik danışman } \\
\text { ihtiyacının giderilmesi }\end{array}$ & A2, A9 & \multirow{2}{*}{$\begin{array}{l}\text { MEB, } \\
\text { Okul } \\
\text { Yönetimi }\end{array}$} \\
\hline & A13 & $\begin{array}{l}\text { Raporlar ve çalıştaylar ile } \\
\text { ihtiyaçların bakanlığa } \\
\text { iletimesi }\end{array}$ & A13 & \\
\hline \multirow[t]{2}{*}{$\begin{array}{l}\text { Velilerin Yetersiz } \\
\text { Desteği }\end{array}$} & $\begin{array}{l}\text { A1, A12, A15, A6, } \\
\text { A17, A18,A8 }\end{array}$ & $\begin{array}{l}\text { Velilere hizmetlerin etkili } \\
\text { tanıtımı }\end{array}$ & A12 & \multirow[t]{2}{*}{$\begin{array}{l}\text { Psikolojik } \\
\text { Danışman }\end{array}$} \\
\hline & A8, A15, A17 & $\begin{array}{l}\text { Velilerin gönülsüzlük, } \\
\text { ilgisizlik tutumlarının } \\
\text { nedenlerinin araștırılmas1 }\end{array}$ & A8, A15, A17 & \\
\hline \multirow[t]{3}{*}{$\begin{array}{l}\text { Müşavirlik } \\
\text { Hizmetlerinde } \\
\text { Aksama }\end{array}$} & $\begin{array}{l}\text { A1, A12, A13, A2, } \\
\text { A16, A18, A6, A19, }\end{array}$ & $\begin{array}{l}\text { Disiplinler aras1 (diğer } \\
\text { branş hocaları) ile birlikte } \\
\text { bir ekip kurulmas1 }\end{array}$ & A2 & \multirow[t]{3}{*}{$\begin{array}{l}\text { Okul } \\
\text { Yönetimi, } \\
\text { Psikolojik } \\
\text { Danışman }\end{array}$} \\
\hline & A21,A24 & $\begin{array}{l}\text { İşbirliği ve etkili iletişimi } \\
\text { artıracak çalışmaların } \\
\text { yapılması }\end{array}$ & A16, A21 & \\
\hline & A5, A16, A21 & $\begin{array}{l}\text { Sinıf rehber ögretmenlerine } \\
\text { hizmet, alan uygulamaları } \\
\text { eğitimi verilmesi }\end{array}$ & A5 & \\
\hline
\end{tabular}


Okul psikolojik danışman eksikliği: Tarama sonucunda, rehberlik hizmetleri çalışmaların hazırlanması ve sunumunda karşılaşılan sorunlar arasında okullarda psikolojik danışman eksikliğinin yaşanması gösterilmiştir.

Çözüm önerileri: Tablo 3'de hizmetlerin işlevselliğini olumsuz etkileyen alt sorunlardan birisi olan psikolojik danışman eksikliği sorununa yönelik çözüm önerilerini içeren araştırmalarda; okullardaki psikolojik danışman ihtiyacının bakanlık ilgili birimleri tarafından tespit edilmesi, ihtiyaç duyulan okullara ivedilikli bir şekilde atama yapılması, okul yöneticilerinin bu ihtiyaçlarını çeşitli raporlar, toplantı ve çalışmalarla il ve bakanlık merkezli sorumlu kişilere ulaştırmak adına çalışmalar yapmaları adına önerileri içeren çalışmalar bulunmaktadır.

Velilerin yetersiz desteği: Tarama sonucunda, rehberlik hizmetleri çalışmaların hazırlanması ve sunumunda karşılaşılan sorunlar arasında velilerin yapılan hizmetlere ilgisiz kalması gösterilmiştir.

Çözüm önerileri: Velilerin kendileri ve öğrencileri adına yapılan çalışmalara katılma konusunda araştırmalar, psikolojik danışmanların velilere rehberlik hizmetlerinin neler olduğu ve öğrencilere bu hizmetlerin olumlu etkilerinin ve gerekliliğinin önemi konusunda çalışmalar yapılması önerilmiştir.

Müşavirlik hizmetlerinde aksama: Tarama sonucunda, rehberlik hizmetleri çalışmaların hazırlanması ve sunumunda karşılaşılan sorunlar arasında rehberlik hizmetleri çalışmalarında görülen işbirliği eksikliği ele alınmıştır.

Çözüm önerileri: Sorunun çözümüne yönelik araştırmalarda; okul yönetimi önderliğinde diğer branş öğretmenlerinin de içerisinde bulunduğu yeni bir kurul hazırlanması, çalışanlar arası etkili iletişimi artırmaya yönelik düzenlenebilecek çalışmalar yapılması, sınıf rehber öğretmenlerinin, öğrencilerin sadece soruları ve sorunları olduğunda değil, dönem başlarında planlanmış olan rehberlik hizmetlerinden detaylı bir şekilde bahsetmeye yönelik çalışmalar yapmanın branşlar arası işbirliğini artıracağına yönelik önerilerde bulunan çalışmalara yer verilmiştir.

\subsection{Mesleki Gelişim ve Tecrübe Kaynaklı Sorunlar ve Çözüm Önerilerine İlişkin Bulgular}

Araştırmalar incelendiğinde okul psikolojik danışmanları, hizmet alanlarına yönelik yapmış oldukları çalışmalarda, kişisel yetersizlik ve tecrübesi eksikliklerinden doğan sorunlar yaşadığı ele alınmıştır. Hissedilen eksiklikler ve bunlara yönelik çözüm önerilerini içeren çalışmalara tablo 4'de yer verilmiştir.

Tablo 4. Mesleki Gelişim ve Tecrübe Eksikliğinden Kaynaklı Alt Sorunlar ve Çözüm Önerileri İçin Kullanılan Makaleler

\begin{tabular}{|c|c|c|c|c|}
\hline Alt Sorun & Kaynak & Çözüm Önerileri & Kaynak & $\begin{array}{l}\text { İlgili } \\
\text { Paydaş }\end{array}$ \\
\hline \multirow{3}{*}{$\begin{array}{l}\text { Lisans eğitiminde } \\
\text { alan ve uygulama } \\
\text { derslerinin az } \\
\text { olması }\end{array}$} & $\begin{array}{lll}\text { A3, } & \text { A12, } & \text { A17, } \\
\text { A4, A18, } & \text { A20, }\end{array}$ & $\begin{array}{l}\text { Uygulamalı ders içeriklerinin } \\
\text { güncellenmesi }\end{array}$ & A6, A17 & $\begin{array}{l}\text { Üniversiteler, } \\
\text { YÖK }\end{array}$ \\
\hline & A12, A17 & $\begin{array}{l}\text { Seçmeli derslerin yaşanabilecek } \\
\text { sorunlara yönelik olması }\end{array}$ & A12, A17 & \\
\hline & A18 & $\begin{array}{l}\text { Alan dersleri uygulamalarına } \\
\text { daha fazla zaman avrılmasi }\end{array}$ & A18 & \\
\hline \multirow[t]{2}{*}{$\begin{array}{l}\text { Hizmet içi eğitim } \\
\text { eksikliği }\end{array}$} & $\begin{array}{l}\text { A2, A12, A13, } \\
\text { A17, }\end{array}$ & $\begin{array}{l}\text { Gelişimsel ve önleyici hizmet } \\
\text { anlayışını artıracak hizmet içi } \\
\text { eğitimler }\end{array}$ & $\begin{array}{l}\text { A2, A13, } \\
\text { A17 }\end{array}$ & $\begin{array}{l}\text { MEB, } \\
\text { Üniversiteler }\end{array}$ \\
\hline & A19 & $\begin{array}{l}\text { Hizmetler konusunda mahalli } \\
\text { ve merkezi çalışmaları artırmak }\end{array}$ & A19 & \\
\hline
\end{tabular}


Lisans eğitiminin yetersizliği: Psikolojik danışmanlanın mesleki gelişim ve tecrübe kaynaklı sorunları arasında gösterilen lisans programlarında rehberlik öğretmenlerinin almış oldukları uygulama ve alan derslerinin müfredatta az yer alması sorunu tablo 4'de ele alınmıştır.

Çözüm önerileri: Sorunun çözümünü içeren araştırmalarda, üniversitelerin mevcut programlarında yer alan seçmeli ve alan derslerinin içeriklerine bakarak bazı güncellemeler yapması, belirlenen seçmeli derslerin daha çok sahada yaşanabilecek sorunlara yönelik olması, lisans programlarının yeterliliğini artırmak üzere öğrencilerin ilgilerini çeken ve ihtiyaç duydukları konularda alan uygulama derslerinin sürelerinin artırılması önerilmiştir.

Hizmetiçi eğitim eksikliği: Araştırmalarda, psikolojik danışmanların mesleki gelişim ve tecrübe kaynaklı sorunları arasında alandaki güncel bilgileri takip etmek ve ihtiyaç duyulan alanlarda hizmetiçi eğitimlerin eksik olduğu ele alınmıştır.

Çözüm önerileri: Sorunun çözümünü içeren araştırmalarda; hizmet alanlarındaki güncel ve bilimsel gelişmeleri takip etmek adına, hizmet içi eğitimlerin artırılması, Milli Eğitim Bakanlığı ve üniversitelerin öncülük edeceği merkezi ve yerel hizmet içi eğitimlerin verilmesi ve bu eğitimlerin gerekliliği konusuna dikkat çekilmesi önerilmiştir.

\section{4. Psikolojik Danışmanların Görevlerine İlişkin Önyargı Sorunları ve Çözüm Öneri Bulguları}

Yapılan çalışmaların bulgu sonuçları incelendiğinde, rehberlik hizmetlerini yerine getirme sorumluluğunda bulunan yönetici ve öğretmenler, psikolojik danışmanın yapmış olduğu çalışmalara karşı olumsuz tutumlar içerisine girmekte ve psikolojik danışmanın sorumluluğunda olmayan işleri rehberlik hizmeti olarak görmektedir. Beklenti ve görev alanları algılarında gözlemlenen sorunlara yönelik belirlenen alt sorunlar ve çözüm önerileri tablo 5'de gösterilmiştir.

Tablo 5. Rehberlik Hizmetleri ve Rehber Öğretmenin Görevlerine İlişkin Önyargılara Ait Alt Problemler ve Çözüm Önerileri

\begin{tabular}{|c|c|c|c|c|c|c|}
\hline Alt Sorun & & Kaynak & & Çözüm Önerileri & Kaynak & $\begin{array}{l}\text { İlgili } \\
\text { Paydaş }\end{array}$ \\
\hline $\begin{array}{l}\text { Yanlış beklenti } \\
\text { anlamlandırmalar }\end{array}$ & ve & $\begin{array}{ll}\text { A12, } & \text { A13, } \\
\text { A18, } & \text { A21, } \\
\text { A23 } & \end{array}$ & $\begin{array}{l}\text { A17, } \\
\text { A22, }\end{array}$ & $\begin{array}{l}\text { Yönetici ve öğretmenlerin } \\
\text { farkındalığını artıracak eğitsel } \\
\text { çalısmalar yapılması }\end{array}$ & $\begin{array}{ll}\mathrm{A} 13, & \mathrm{~A} 12 \\
\mathrm{~A} 21, & \text { A17 } \\
\mathrm{A} 18, & \text { A23 }\end{array}$ & MEB \\
\hline
\end{tabular}

\begin{tabular}{|c|c|c|c|c|}
\hline \multirow[t]{2}{*}{ Görev dışı sorumluklar } & $\begin{array}{l}\text { A1, A4, A6, A7, } \\
\text { A15, A21,A22 }\end{array}$ & $\begin{array}{l}\text { Eğitim kurumlarındaki rol ve } \\
\text { sorumluluklarının } \\
\text { netleştirilmesi }\end{array}$ & $\begin{array}{l}\text { A6, } \\
\text { A15 }\end{array}$ & \multirow[t]{2}{*}{$\begin{array}{l}\text { MEB, Okul } \\
\text { Yönetimi }\end{array}$} \\
\hline & A15 & $\begin{array}{l}\text { Rol ve sorumluluk diş1 } \\
\text { beklentilere girilmemesi }\end{array}$ & A15 & \\
\hline
\end{tabular}

Yanlış beklenti ve anlamlandırmalar: Rehberlik hizmetlerine yönelik olumsuz tutum ve davranışlara sahip yönetici ve öğretmenlerin, kendi abartılı beklentileri ile yapılan çalışmaların sonuçlarına dair oluşturdukları istekler arasındaki uyumsuzluklar, sunulan hizmetleri olumsuz bir biçimde etkilemektedir. Özellikle yapılan araştırmalarda, rehberlik hizmetlerine yönelik çalışmaların anında sonuç vereceğine dair beklentiler, öğrencilerde var olan problemin anında ortadan kaybolması şeklinde bir alg1 oluşturarak, psikolojik danışmanı zora soktuğunu ve çalışmaları olumsuz açıdan etkilediğini göstermektedir.

Çözüm önerileri: Araştırmalarda, psikolojik danışmanların görev ve sorumluluklanına ilişkin farkındalık kazandırmak amaçlı, okul idaresi ve öğretmenlere yönelik bakanlık destekli eğitsel çalışmaların yapması önerilmektedir. 
Cengiz, S., \& Bilgiz Öztürk, Ș. (2020). Psikolojik danışma ve rehberlik servisinde karșlașılan sorunlar ve çözüm önerileri: Bir metasentez çalışması. Journal of Human Sciences, 17(4), 1069-1082. doi:10.14687/ihs.v17i4.6054

Görev dişı sorumluluk: Araştırmalarda, okul rehberlik hizmetlerinin içeriğini, görev ve sorumluluk alanlarını yeterince bilmeyen yöneticilerin; rehberlik hizmeti olarak adlandırılmayacak idari işleri işleri rehberlik hizmeti olarak adlandırması sorun olarak görülmektedir.

Çözüm önerileri: Bu sorunla alakalı olarak ilgili araştırmalarda, yönetmelikte yer alan görev ve sorumluluklardaki boşlukların doldurularak, daha net bir şekilde belirlenmesi, hizmetlerin yürütülmesinde okuldaki her paydaşın görev ve sorumluluklarını bilmesi ve sorumlulukları dışındaki işlerin psikolojik danışmandan beklenmemesi önerilmiştir.

\subsection{Psikolojik Danışma ve Rehberlik Hizmetleri Politikalarına İlişkin Sorunlar ve Çözüm Önerilerine İlişkin Bulgular}

İncelenen çalışmalar sonucunda rehberlik hizmetleri politikalarına ilişkin oluşturulan alt sorunlar ve çözüm önerileri tablo 6'da gösterilmiştir.

Tablo 6. Rehberlik Hizmetleri Politikalarnna İlişkin Sorunlar ve Çözüm Önerileri

\begin{tabular}{|c|c|c|c|c|}
\hline Alt Sorun & Kaynak & Çözüm Önerileri & Kaynak & İlgili Paydaş \\
\hline $\begin{array}{l}\text { Rehberlik dersinin } \\
\text { kaldırılmasi }\end{array}$ & A18, A20 & $\begin{array}{l}\text { Rehberlik ders saatinin } \\
\text { artirlmasi }\end{array}$ & A20 & MEB \\
\hline $\begin{array}{l}\text { Eş zamanlı } \\
\text { görevlendirme } \\
\text { sorunu }\end{array}$ & A22 & $\begin{array}{l}\text { Üniversite, dernek ve ilgili } \\
\text { kurumlardan görüş almak }\end{array}$ & A22 & MEB \\
\hline
\end{tabular}

Rehberlik saatinin bazı sınıf düzeylerinde kaldırılması: Araştırmalar incelendiğinde, farklı okul tür ve kademelerinde, okul rehberlik saatinin bazı sınıf dereceleri için kaldırılmasının yapılacak çalışmalanı olumsuz etkilediği belirtilmiştir.

Çözüm önerileri: Taranan araştırmalarda okullarda rehberlik saatlerinin yeniden düzenlenmesi önerilmiştir.

Eş zamanlı görevlendirmeler: Araştırmalarda psikolojik danışmanlara, okul rehberlik öğretmeni olmayan okullarda rehberlik hizmetlerinin yürütülmesi adına yapılan görevlendirmelerin verimli olmadığını, çalışmaların aksamasına yol açtığı belirtilmiştir.

Çözüm önerileri: Araştırma sonuçlarında akademisyenlerin, psikolojik danışma ve rehberlik derneği yöneticilerinin, ilgili eğitim sendikalarının kısacası alanla ilgili birim ve kişilerin bir araya gelerek çözüm yolları üretmesi ve bu çözümleri hayata geçirmeleri önerilmiştir.

\section{Tartışma ve Sonuç}

$\mathrm{Bu}$ çalışmada, psikolojik danışmanların okullarda psikolojik danışma ve rehberlik hizmetlerini yerine getirmede karşılaştıkları sorunlar ve çözüm önerilerini sistematik bir şekilde bir araya getirerek bu çalışmaların derlenmesi amaçlanmıştır. Elde edilen araştırmalara bağlı olarak yaşanan problemler; fiziki koşul ve imkanlardan kaynaklı sorunlar, çalışmaların hazırlanması ve sunumuna dair sorunlar, mesleki gelişim ve tecrübe eksikliğinden oluşan sorunlar, hizmetlere ve görev tanımına ilişkin önyargı sorunları, rehberlik hizmetleri politikalarına ilisskin sorunlar başlığ1 altında toplanmıştır. Ayrıca bu sorunlara ilişkin kaynakların taranması sonrası alt sorunlar ve çözüm önerileri elde edilmiş ve sınıflandırma yapılmıştur.

İlk problem alanı olarak belirlenen fiziki koşul ve imkanlardan kaynaklı sorunlar başlığı altında; rehberlik servisinin bulunmaması, mevcut rehberlik servisindeki araç, gereç yetersizliği ve toplantı ve sunum yapılabilecek bir odanın bulunmaması alt sorunları saptanmıştır. Ayrıca taranan çalışmalarda bu sorunların çözümü için okullardaki rehberlik servisi odası eksikliğinin okul müdürü tarafindan giderilmesi gerekli malzemelerin temin edilmesinin gerektiği yönünde öneriler de bulunulmuştur. Rehberlik öğretmenlerinin hizmetleri yürütme esnasında kullanacakları hususi bir odanın bulunması gerekmektedir. Ancak çalışmaların yürütüleceği, hizmetlerin süreç-işleyiş planlarının hazırlanacağı, fayda görmek isteyen bireylerin gelebileceği bir okul rehberlik servisinin olmaması yapılacak çalışmaları ve psikolojik danışmanın motivasyonunu olumsuz olarak etkilemektedir (Akpınar ve Bengisoy, 2017). Yine psikolojik danışmanın, yapacağı çalışmaları 
sunmak adına okulda uygun bir toplantı veya konferans salonu olmasını beklemektedir. Çünkü doğrudan öğrencilere ve velilere sunulacak hizmetlerin ve iletişimin etkili olabilmesi, sunulacak ortamın özellikleriyle ilişkilendirilmektedir (Ünal ve Ünal, 2010). Her sınıfa ayrı ayrı girmek, gelen velilerle ayaküstü görüşmeler yapmak ve sunulacak hizmetlerin içeriğinin sadece sözlü bir şekilde aktarilmasi, sunulan hizmetleri olumsuz etkilemektedir ( Kaya ve Kaya, 2017).

Okul psikolojik danışmanlarının yaşadığı bir diğer sorun alanı, çalışmaların hazırlanması ve sunumuna dair sorunlar olarak belirlenmiştir. Bu sorun genel olarak psikolojik danışmanların motivasyonunu düşürerek, uygulamaların verim düzeyini azalmasına sebep olan faktörler olarak değerlendirilmektedir. Okullardaki psikolojik danışman normunun doldurulamaması, sorumlu olunan öğrenci sayısının fazlalığı, velilerin kendilerine sunulan hizmetlere katılımı konusundaki isteksizliği, yönetici ve öğretmenlerin işbirliği sorunu bu problem alanı başlığı altında toplanan alt sorun alanlarındandır. Türkiye'de rehberlik hizmetlerine duyulan ihtiyaç günden güne artmakta olup bu ihtiyacı karşılamak adına okullardaki mevcut öğrenci sayılarını göz önüne alarak, psikolojik danışman atamalarına öncelik verilmesi gerekmektedir. Çünkü etkili rehberlik hizmetleri ile okullardaki akademik faaliyetlerin yanı sıra sosyal ve duygusal faaliyetlerde de verimlilik düzeyi artabilecektir. Öğrenci sayısının fazla olması psikolojik danışmanların performanslarını olumsuz açıdan etkileyebilecek temel unsurlardandır. Bu durum etkinliklerin verimini azaltmanın yanı sıra, öğrenci ve öğretmenlerin ilgi ve istek düzeyini de etkilemektedir (Özabac1, Sakarya ve Doğan, 2008). Rehberlik hizmetlerinin veli ve okul idaresi ile işbirliği boyutları da hizmetlerin yürütülmesinde oldukça önemlidir. Rehberlik servisi tarafindan kendilerine sunulacak hizmetlere katulım konusunda yöneticilerin işbirliğinden uzak tavırları (Yerin Güneri, Büyükgöze Kavas ve Koydemir, 2007) ve velilerin isteksiz ve sorumsuz olmalanı yapılacak çalışmaların işlevselliğini ve sürekliliğini olumsuz olarak etkilemektedir (Çilekar, 2014).

Üniversite eğitiminin ardından okullarda görev alan psikolojik danışmanlanın mesleki gelişim ve tecrübe eksikliğinden oluşan sorunlarda araştırmalarda ele alınmış olup, özellikle uygulamaya yönelik çalısmalarda bazı aksaklıklara sebep olduğu belirtilmiştir. Araştırma makaleleri incelendiğinde, psikolojik danışma ve rehberlik lisans programlanında yer alan uygulama ve alan derslerinin süre ve içerik bakımından yetersiz bulunması, bu eksiklikleri gidermek için uygun bir ortam olan hizmet içi eğitimlerin yetersiz kalması bu soruna neden olabilecek unsurlar arasında gösterilmektedir (Atıcı ve Çam, 2016; Doğan, 2009;). Bu sorunların çözümü ise pratik uygulamalarda ve karşılaşılan sorunlanı çözme noktasındaki eksikliklerin saptanarak, mevcut lisans programlarında güncellemelere gidilmesiyle hizmet içi eğitimlerin geliştirilmesinin gerekliliği şeklinde açıllanmıştır. Güven, Kılıç, Hayran ve Büyüksevindik (2016) psikolojik danışmanların sorumluluğunda olan hizmetleri yerine getirmede etkili olabilecek mesleki gelişimlerinin hizmetiçi çalışmalara desteklenmesi gerektiğini belirtmiştir. Ayrıca hizmetlerin uygulanmasında psikolojik danışmanların kişisel yetersizlik hissini oluşturarak, düşük başarı hissi yaşatan ve çalışmaları olumsuz etkileyen sorunların sebeplerinden biriside, alınan lisans eğitiminin yetersizliğidir. Sunulacak hizmetlerin içeriğine hakim olma, uygulama becerisinin gelişmişliği, sorun ve olası krizlere müdahale yeterliliği, alınan eğitimlere bağlıdır. Bu sebepten dolayı üniversitelerin mevcut programlarında yer alan seçmeli ve alan derslerinin içeriklerine bakarak bazı güncellemeler yapması önerilmektedir (Dinçel ve Demirtaş Zorbaz, 2015). Lisans programlarında yer alan programlar ve hizmetiçi çalışmaların eksikliğini süpervizör tarafindan tamamlamak isteyen psikolojik danışmanlar, alanda uzman bireylere ulaşma noktasında da sorun yaşamaktadır. Özellikle kırsal bölgelerde görevli öğretmenler kapsamlı rehberlik programına göre uyguladıkları hizmetler esnasında yaşadıkları sorunları çözmek için, kendisine yardımcı olacak deneyimli bir çalışana ihtiyaç duymaktadır. Fakat bu ihtiyaç çoğu zaman karşılanamamaktadır (Bengisoy ve Özdemir, 2019).

Rehberlik hizmetlerini yerine getirme sorumluluğunda bulunan yönetici ve öğretmenler, psikolojik danışmanın yapmış olduğu çalşsmalara karşı olumsuz tutumlar içerisine girmekte ve psikolojik danışmanın sorumluluğunda olmayan işleri rehberlik hizmeti olarak görmektedir. Sunulan hizmetlerin etkisini kısa sürede görmek, rehberlik servisini problem çözme yeri olarak algılamak şeklindeki düşünceler, yapılan çalışmalara ve rehberlik öğretmenine olumsuz bir biçimde 
yansımaktadır. Rehberlik hizmetlerine yönelik olumsuz tutum ve davranışlara sahip yönetici ve öğretmenlerin, kendi abartılı beklentileri ile yapılan çalışmaların sonuçlarına dair oluşturdukları istekler arasındaki uyumsuzluklar, sunulan hizmetleri olumsuz bir biçimde etkilemektedir (Özabacı, Sakarya ve Doğan, 2008). Özellikle çalışmaların anında sonuç vereceğine dair beklentiler, öğrencilerde var olan problemin anında ortadan kaybolması şeklinde bir alg1 oluşturarak, psikolojik danışmanı zora sokmakta ve çalışmaları olumsuz açıdan etkileyebilmektedir (Tagay ve Savi Çakar, 2017). Ayrıca okul rehberlik hizmetlerinin içeriğini, görev ve sorumluluk alanlarını eksik bilen yöneticiler; rehberlik hizmeti olarak adlandırlmayacak idari işleri rehberlik hizmeti olarak adlandırmakta ve psikolojik danışmandan bunları yerine getirmesini beklemektedir. Sonucunda da asıl hizmetler aksamakta ve yöneticilerle psikolojik danışman arasında anlaşmazlıklar ortaya çıkmaktadır (Avc1, Çeçen Eroğul ve Zeybek, 2017).

Psikolojik danışmanların çalışmalarında yer alan bir diğer sorunda rehberlik hizmetlerine yönelik geliştirilen politikalardan doğmaktadır. Bu sorunlardan birisi de farklı okul kademelerinde, okul rehberlik saatinin bazı sınıf dereceleri için kaldırılması sorunudur. Okul psikolojik danışmanlarının yapacağı çalışmalardan bazılarının uzun süreli olması, geri dönütlerin yüz yüze alınması gerektiğinden diğer branş öğretmenlerinden ihtiyaç olduğunda o ders saatinin alınması söz konusu olabilmektedir (Akay, Türk, Mercan ve Urtekin, 2019). Ancak bu durum ilgili dersin planlamasında, öğrenci-öğretmen motivasyonunda bazı olumsuz yansımalar doğurmaktadır (Ateş, 2018). Bu olumsuz durumlardan dolayı okul rehberlik ders saatlerinin sinıf düzeylerine göre, okullarda tekrar uygulanması amacıyla alınan kararın gözden geçirilmesi önerilebilir. Yine son yıllarda hukuki yönden psikolojik danışmanların sıkça şikayet ettiği sorunlardan biriside yapılan hatalı görevlendirmelerdir (Koçak Bıçak, Ottekin Demirbolat, 2019). Kendi okulunda rehberlik hizmetlerini yürütme noktasında yaşadığı sorunlarla birlikte görevlendirme gittiği okulda da benzer sorunların yaşanması mesleki motivasyonu düşürebilmektedir. Ayrıca kendi okulunda işlerin yarıda kalması, gittiği okulda öğretmen ve öğrencileri yeterince tanıyamamak sunulan hizmetlerin kalitesini olumsuz etkileyebilmektedir (Dağ vd. 2009).

Sonuç olarak araştırmaya dahil edilen çalışmalar ve alan yazında yer alan diğer araştırmalar rehberlik hizmetlerini yerine getirme noktasında karşılaşılan sorunların tarih kısıı olmadan karşımıza çıkabileceğini göstermektedir. Bu durum göz önünde alındığında, bu tarz sorunları ele alan çalışmaların bir araya getirilmesi, ilgili paydaşlara çözüm yollarının sunulması problemlerin fark edilerek tedbir çalışmalarının alınmasına katkı sağlayacağı düşünülmektedir. $\mathrm{Bu}$ bilgiler doğrultusunda birtakım önerilerde bulunulmuştur.

\section{Öneriler}

1-) Yapılan bu araştırma, rehberlik hizmetleri alanında günümüzde var olan sorunlara dikkat çekmektedir. Geçmişte var olan bazı sorunların günümüzde hala devam ediyor olması bu sorunların çözümü için ilgili tüm kişi ve kurumların işbirliği içinde olmasını gerektirmektedir. Bu nedenle yapılacak yeni çalışmalarda işbirliği algısı vurgulanmalıdır.

2-) Bu alanda çalışan kişilerin, bu sorunlara karşı daha fazla bilgi sahibi olması olası bir durumdur. Fakat meslekte henüz çalışma adayı olan kişilerin de bu sorunlara bakış açısı ve çözümlere ilişkin farkındalıkları, nicel ve nitel araştırmalar aracıllğı ile incelenebilir. Bu durum mesleğe geçiş sürecinde yaşanan aksaklıkların azaltılmasında etkili olabilecektir.

3-) Sorunlara ilişkin yapılmış çalışmalarda belirlenen sorunların bazılarında çözüm önerilerinin yetersiz olduğu saptanmış olup, belirlenecek sorunların çözümlerinin ve bu çözümlerin gerçekleştirilme sürecinin de ele alınması araştırmacılar ve uygulamacılar açısından önerilmektedir.

4-) Rehberlik hizmetlerinden faydalanacak bireylere bu hizmetlerin sağlanmasında; lisans eğitim programlarının uygulamada yaşanan sorunları çözmek üzere gözden geçirilmesi, ve çalışmaların verimliliğini artırmak adına alan uzmanları, okul aile birlikleri, diğer eğitimcilerle sorunların çözümüne ilişkin politikalar üretilmesi sağlanabilir. 
Cengiz, S., \& Bilgiz Öztürk, Ş. (2020). Psikolojik danışma ve rehberlik servisinde karşılaşılan sorunlar ve çözüm önerileri: Bir metasentez çalışması. Journal of Human Sciences, 17(4), 1069-1082. doi:10.14687/jhs.v17i4.6054

\section{Kaynakça}

Akay, S. , Türk, F. , Mercan, Ö. \& Urtekin, F. (2019). Psikolojik danışmanların bakış açısından rehberlik hizmetleri yönetmeliği'nin incelenmesi . Inönü Üniversitesi Eğitim Fakültesi Dergisi, 20(3), 891-918.

Akpınar, B. \& Bengisoy, A. (2017). Rehber öğretmenlerin okul müdürlerinin rehberlik hizmetlerine ilişkin görüşleri . Current Research in Education , 3 (3) , 129-141.

Ateş, T. (2018). Ë̆itsel mesleki ve kişsisel rehberlik alanlarnnda yapılan faaliyetlerin incelenmesi: Ram kaynaklarna dayalı bir çallsma. Karadeniz Teknik Üniversitesi, Trabzon.

Atıc1, M., \& Çam, S. (2016). Okullarda PDR uygulamaları dersine ilişkin öğrenci görüşlerinin incelenmesi. Turkish Psychological Counseling and Guidance Journal, 4(39).

Avc1, R , Çeçen Eroğul, A , Umut Zeybek, S . (2017). Psikolojik danışma ve rehberliğe (pdr) yönelik mitler ölçeğinin geliştirilmesi ve rehberlik dersinin pedagojik formasyon öğrencilerinin pdr'ye yönelik mitleri üzerindeki etkisi . Türk Psikolojik Danısma ve Rebberlik Dergisi , 7(48), 15-29.

Bengisoy, A , Özdemir, M . (2019). Psikolojik danışman/rehber öğretmenlerin bakış açısıyla psikolojik danışma ve rehberlik alanının sorunları. Kıbrıs Türk Psikiyatri ve Psikoloji Dergisi , 1(3), 189193.

Çilekar, H. (2014). Müdürlerin okullardaki rebberlik uygulamalarna yönelike liderliği ile rehberlike uygulamalar arasindaki ilişki: Yayımlanmamış Yüksek Lisans Tezi. Sabahattin Zaim Üniversitesi, İstanbul.

Çokamay, G., Kapçı, E. G., \& Sever, M. (2017). Okul ruh sağlı̆̆ hizmetlerinde yaşanan sorunlar: Psikolojik danışmanların görüşleri. İlköğretim Online, 16(4), 1395-1406.

Dinçel, E.F. \& Demirtaş-Zorbaz, S. (2015). Okul psikolojik danışmanlarmnn bižmet içi eğitim ibtiyaçlar. 13. Ulusal Psikolojik Danışma ve Rehberlik Kongresi, Mersin.

Doğan, O. (2009). Hizmetiçi eğitime katilimin eğitim ögretim sürecine etkisi ile ilgili yönetici ve ögretmen görüsleri. Yayımlanmamış Yüksek Lisans Tezi. Maltepe Üniversitesi, İstanbul.

Glesne, C. (2014). Nitel araștırmaya giriş (4. Baskı). A. Ersoy ve P. Yalçınoğlu. (Çev. Ed.). Ankara: Anı Yayinc1lik.

Günay, G. \& Özbilen, F. M. (2014). İlköğretim öğretmenlerinin okul nöbet görevleri üzerine bir değerlendirme. Mersin Üniversitesi Ë̈itim Fakültesi Dergisi, 10(3), 64-78

Gysbers, N.C. \& Henderson, P. (2014). Developing and Managing Your School Guidance Program. 4th Ed., Alexandria, VA: ACA.

Hamamc1, Z., Murat, M. \& Çoban, A. E. (2004) Gaŗiantep’teki okullarda çalısan psikolojik damısmanlarm mesleki sorunlarmm incelenmesi. XIII. Ulusal Eğitim Bilimleri Kurultay1, 6-9 Temmuz 2004. Malatya: İnönü Üniversitesi, Eğitim Fakültesi.

Hohenshil, T. H., Amundson, N. E. ve Niles, S. G. (Ed.). (2015). Counseling around the World: An international handbook. John Wiley \& Sons.

İkiz, F. E. (2016). Psikolojik damısma ve psikoterapide kuramlar ve yenilikẹi yaklassımlar. Ankara: Nobel Akademik Yayıncllik.

Karaca, R. \& İkiz, E. (2010). Psikolojik danışma ve rehberlikte çağdaş bir anlayıș (2. Baskı). Ankara: Nobel Yayın Dağıtım.

Kaya, F. \& Kaya, S. (2019). Ortaöğretim kurumlarindaki psikolojik danişma ve rehberlik hizmetlerinin denetiminde karşilaşilan sorunlara ilişkin bakanlik denetçilerinin görüşleri. Mehmet Akif Ersoy Üniversitesi Eğitim Bilimleri Enstitüsü Dergisi, 5(7), 56-75.

Koçak Bıçak, D. \& Ottekin Demirbolat, A. (2019). Okul psikolojik danışmanlarının okul yöneticileri ve öğretmenlerden beklentileri. Türk Eg̈itim Bilimleri Dergisi , 17 (2) , 236-257.

Nazli, S. (2014). Police academy guidance and psychological counseling department's transition process to developmental guidance model. Egitim Bilimleri Fakultesi Dergisi, 47(1), 259.

Owen, F. K. \& Qwen, D. (2008). Okul psikolojik danışmanların rol ve işlevleri: Yöneticiler ve psikolojik danışmanın görüşleri. Ankara Üniversitesi Eğitim Bilimleri Fakültesi Dergisi, 41(1), 207221.

Özabac1, N., Sakarya, N., \& Doğan, M. (2008). Okul yöneticilerinin okuldaki psikolojik danişma ve rehberlik hizmetlerine ilişkin görüşlerinin değerlendirilmesi. Balıeesir Üniversitesi Sosyal Bilimler Enstitüsü Dergisi, 11(19), 8-22. 
Cengiz, S., \& Bilgiz Öztürk, Ș. (2020). Psikolojik danışma ve rehberlik servisinde karșlașılan sorunlar ve çözüm önerileri: Bir metasentez çalışması. Journal of Human Sciences, 17(4), 1069-1082. doi:10.14687/ihs.v17i4.6054

Özaydın, S., Şahin, S., \& Siyez, D. M. (2019). Liselerde görev yapan öğretmen ve idarecilerin, psikolojik danışmanların nöbet tutmasının okul psikolojik danışma ve rehberlik hizmetleri üzerindeki etkisine ilişkin görüşleri. Türk Psikolojik Danışma ve Rehberlike Dergisi, 9(55), 11791211.

Pişkin, M. (2006). Türkiye'de psikolojik danısma ve rehberlik bizmetlerinin dünü, bugünü ve yarmn. M.Hesapçıŏlu, ve A. Durmuş (Ed.) Türkiye'de eğitim bilimleri: Bir bilanço denemesi kitabı içinde. Ankara: Nobel.

Poyraz, C. (2007). Ortadereceli okullarda yürütülen rehberlike bizmetleri üzerine bir arastorma (A study On Counseling Services At High Schools). Unpublished doctoral thesis, İstanbul University, Institute of Social Sciences, İstanbul, Turkey.

Selen, N. (2008). Liselerdeki psikolojik damısma ve rehberlik servislerinin algulanan etkililigïnin bazı değiskenlere göre incelenmesi. Yayımlanmamış Yüksek Lisans Tezi. Ege Üniversitesi, İzmir.

Toprakc1, E. \& Esen Altunay (2014) The relationship of psychological counseling and guidance staff and their administrators (a qualitative analysis in the stories). Elementary Education Online, 13(2), 526-545.

Tuzgöl Dost, M. \& Keklik, İ . (2012). Alanda çalışanların gözünden psikolojik danışma ve rehberlik alanının sorunları. Mehmet Akif Ersoy Üniversitesi Eüitim Fakültesi Dergisi , 1(23) , 389-407.

Ünal, A., \& Ünal, E. (2010). Öğretmen ve öğrencilerin rehber öğretmeni algılamalarına ilişkin bir durum çalışması. Uluslararası Insan Bilimleri Dergisi, 7(2), 919-945.

Yerin-Güneri, O., Büyükgöze-Kavas, A. \& Koydemir, S. (2007). Okul psikolojik danısmanlarmm psikolojik gelisimi: Acemilikten olgunlaşmaya giden yol. İçinde R. Özyürek, F. Korkut-Owen ve Dean W. Owen (Ed.), Gelişen Psikolojik Danışma ve Rehberlik (Cilt 1) (s. 139-161). Ankara: Nobel Yayın Dağıtım.

Yeşilyaprak, B. (2012).Mesleki rehberlik ve kariyer danışmanlığında paradigma değişimi ve Türkiye açısından sonuçlar: geçmişten geleceğe yönelik bir değerlendirme. Kuram ve Uygulamada Eğitim Bilimleri, 12(1), 97-118.

Yıldız, A. D., \& Türk, E. G. (2018). Okul psikolojik danışmanlarının görev sınırları ve sorumluluklarının metaforlar ile analizi. Kastamonu Ë̈itim Dergisi, 26(4), 1207-1216.

\section{Ek-1}

\section{Extended English Summary}

Purpose and Significance: Counseling in schools is one of the most important components of education. Counseling which occupies a very important place in the entire educational process in schools is defined as an auxiliary stage that requires professional, systematic and expert participation in all students, parents, teachers and school management. The students who need personal, professional, or educational counseling can apply as counselors to their appointed or appointed teachers in schools. But in the process counselors face many problems related to their students personal or relational problems and help them overcome these problems. During these services on various issues consultants face many different problems and these problems can negatively affect their business performance. In order to raise awareness, it is vital that a broad perspective is represented to all education researchers, ministerial representatives and field experts who are considered responsible for solving the problems mentioned

Method: The aim of the study was to examine the academic research in the literature on the problems faced by school guidance teachers during the guidance service, the solutions of these problems and all responsible individuals at the solution stage of these problems. In this context, a total of twenty-five academic articles prepared for the Turkish paradigm and with full accessibility were examined and the basis for this research was established. Articles that meet the relevant criteria for the determination of the "school counseling services problems and solutions", "problems and solutions in guidance services" and "psychological counseling problems and solutions" conducted research with keywords. The various databases. Each work used in the study was encoded and shown as A1, A2, A3, A4 ... Each indication, conclusion and recommendation included in the study was 
examined and the final result was taken into Nvivo 11 software. Later tables were created about how many times these studies were used to suggest problems and solutions. The encoded data is categorized under the main problems heading sub-problems and solution suggestions are encoded under the secondary headings. All identified problems and solutions were subjected to the process of synthesis.

Findings: The obtained problems have been categorized in five different titles; problems due to physical conditions and facilities, issues related to preparation and presentation of the services, problems of lack the of professional development and experience, prejudice problems for services and job definition, and problems from bureaucracy. Next, each and every title has been deeply analyzed in order to create the sub problems. After the analysis, these sub-problems have been determined and added below the five main problems title and the solutions have been

presented for those who are thought to be responsible for those sub problems. In order to clarify all the points regarding the main problems of the research data, the sub-problems, those who are responsible for the problems and the solutions, all the components have been separately categorized. Below every table, explanations have been added as "the main problems of the research data, the subproblems, those who are responsible for the problems and the solutions". Among the sub problems, which are thought to be related with the main problems, most often, "lack of quantity of counselors", "the lack of cooperation between the teachers and the administers on the services", "the lack of equipment in the counseling service", "including various other works which are not in the job definition" and "inadequacy in the undergraduate program" are mentioned.

The solution of these problems belongs to the Ministry of Education, school administrators, consultants, education unions, university units and the PDR Association. This is because it requires all units to cooperate and make a joint statement on the issue. Consulting service is too comprehensive and important to be controlled only by an association or a person. Because individuals with mental health will act in a positive direction both financially and spiritually and will contribute to the level of development of the country. In relation to all the facts mentioned above the subject has a significance that cannot be ignored and will serve as the basis for later research as a broad perspective.

Discussion and Conclusion: The aim of this research is to draw attention to the current problems in the field of consulting services. Future researchers on the same subject will have the ease of finding more information on the subject. But candidates perspectives on problems can only be studied through qualitative and quantitative research aimed at their awareness of problems and their solutions. It is also hoped that this investigation will raise awareness of those responsible for solving the problems collected during this investigation. Thanks to this research, it will be possible to complete the missing parts on related issues and make a reference to future research.

\section{Ek-2}

\section{Kaynaklar (Rehberlik Hizmetleri Sorun ve Çözüm Önerileri Tespitinde Kullanılan Çalışmalar)}

A1. Akpınar, B., \& Bengisoy, A . (2017). Rehber öğretmenlerin okul müdürlerinin rehberlik hizmetlerine ilişkin görüşleri. Current Research in Education, 3(3), 129-141.

A2. Arıcıoğlu, A., \& Tagay, Ö. (2008). Okullarda ruh sağllğı hizmetleri. Kuramsal Eğitimbilim Dergisi, 1(2), 76-99.

A3. Aydın, G. (1988). Üniversite öğrencilerinde depresyon, açıklama biçimi ve akademik başarı ilişkisi. Türk Psikoloji Dergisi, 6(22), 6-12.

A4. Bakioğlu, A. \& Gayık-Asyalı, S. (2005). Rehber öğretmenlerin bulundukları kariyer evrelerine göre okul yönetimini algılayışlarının niteliksel olarak incelenmesi. Marmara Üniversitesi Eğitim Bilimleri Dergisi, 40, 13-29.

A5. Çil, İ., Tokat, M. A., Türkan, Y. S. \& Doğan, N. (2014). Temel eğitim kurumlarında e-rehberlik ve danışmanlık karar destek sistemi. Hacettepe Üniversitesi Eğitim Fakültesi Dergisi, 29(2), 34-56. 
Cengiz, S., \& Bilgiz Öztürk, Ş. (2020). Psikolojik danışma ve rehberlik servisinde karşılaşılan sorunlar ve çözüm önerileri: Bir metasentez çalışması. Journal of Human Sciences, 17(4), 1069-1082. doi:10.14687/jhs.v17i4.6054

A6. Çokamay, G., Kapçı, E., \& Sever, M. (2017). Okul ruh sağlı̆̆ı hizmetlerinde yaşanan sorunlar: Psikolojik danışmanların görüşleri. İlkëğretim Online, 16(4), 1395-1406.

A7. Doğan, S. (1996). Türkiye' de psikolojik danışma ve rehberlik alanında meslek kimliğinin gelişimi ve bazı sorunlar. Türk Psikolojik Damısma ve Rebberlik Dergisi, 2(7), 32-44.

A8. Donat Bacıoğlu, S., Onat Kocabıyık, O., \& Malkoç, A. (2017). Rehberlik ve psikolojik danışmanlık öğrencilerinin okullardaki rehberlik servisini değerlendirmeleri. Türk Psikolojik Danısma ve Rebberlik Dergisi, 7(48), 45-62.

A9. Güven, M. (2009). Millî Eğitim Bakanlı̆̆ müfettişlerinin okul rehberlik hizmetleri ve denetimiyle ilgili görüşleri. Uluslararası Sosyal Arasstırmalar Dergisi, 2, 171-179.

A10. Hatunoğlu, Y.,\& Hatunoğlu, Y. (2006). Okullarda verilen rehberlik hizmetlerinin problem alanlar1. Kastamonu Eğitim Dergisi, 14(1), 333-338.

A11. Karaküçük, S. (2010). Okul rehberlik servislerinin fiziksel/mekânsal koşullarının incelenmesi. Erciyes Üniversitesi Sosyal Bilimler Enstitïsü Dergisi, 1(28), 421-440.

A12. Karataş, İ. \& Polat, M. (2013). Okul yöneticilerinin rehberlik hizmetlerine bakış açıları üzerine okul rehber öğretmenlerinin görüşleri. Mus Alparslan Üniversitesi Sosyal Bilimler Dergisi, 1(1), 105-124.

A13. Karataş, Z. \& Baltac1, H. Ş. (2013). Ortaöğretim kurumlarında yürütülen psikolojik danışma ve rehberlik hizmetlerine yönelik okul müdürü, sınıf rehber öğretmeni, öğrenci ve okul rehber öğretmeninin (psikolojik danışman) görüşlerinin incelenmesi. Abi Evran Üniversitesi Kırşehir Eğitim Fakültesi Dergisi, 14(2), 427-460.

A14. Kepçeoğlu, M. (1976). Okul danışmanlarının mesleki problemleri. H.Ü. Sosyal ve beşeri Bilimler Dergisi, 8, 68-80.

A15. Nuryüz, Ö., Dağlar, E \& Yeşiloğlu Y. (2016) lise düzeyinde çalışan psikolojik danışmanların mesleki rehberliğe bakış açılarının incelenmesi üzerine nitel bir araştırma. Uluslararası Hakemli Psikiyatri ve Psikoloji Arastormalan Dergisi, 1(5),111-116.

A16. Okur, Y. (2009). Türkiye'de rehberlik ve danışmanlık anlayışıyla denetim: uygulama, sorunlar ve değerlendirmeler. Denetişim, 2,44-51.

A17. Parmaksız, İ.\& Gök, A. (2018). Okul psikolojik danışmanlarının psikolojik danışma ve rehberlik hizmetlerinin yürütülmesinde karşılaştıkları güçlükler. Mebmet Akif Ersoy Üniversitesi Ë̆gitim Fakültesi Dergisi, 47, 247-265.

A18. Tagay, Ö.,\& Savi-Çakar, F. (2017). Okullarda yürütülen psikolojik danışma ve rehberlik hizmetlerine ilişkin okul psikolojik danışmanlarının görüşleri. Abi Evran Üniversitesi Kurşebir Eğitim Fakültesi Dergisi, 18(3), 1168-1186.

A19. Tan, H. (1974). Ülkemizde rehberlik ve psikolojik danışma çalışmalarında gelişmeler ve sorunlarr. Psikoloji Calssmalar, 11, 33-48.

A20. Terzi, S.., Tekinalp, B. E., \& Leuwerke, W. (2011). Psikolojik danışmanların okul psikolojik danışma ve rehberlik hizmetleri modeline dayalı olarak geliştirilen kapsamlı psikolojik danışma ve rehberlik programını değerlendirmeleri. Pegem Eğitim ve Ögretim Dergisi, 1(1), 51-60.

A21. Toprakç1, E.,\& Altunay, E. (2014). Psikolojik danışma ve rehberlik personelinin yöneticileriyle ilişkileri (Anılar bağlamında nitel bir analiz). İlkögretim Online, 13(2), 526-545,

A22. Tuzgöl Dost, M.,\& Keklik, İ . (2012). Alanda çalışanların gözünden psikolojik danışma ve rehberlik alanının sorunları. Mehmet Akif Ersoy Üniversitesi Eğitim Fakültesi Dergisi, 1(23), 389407.

A23. Ünal, A.,\& Ünal, E. (2010). Öğretmen ve öğrencilerin rehber öğretmeni alg1lamalarına ilişkin bir durum çalısması. Uluslararası Insan Bilimleri Dergisi, 7(2), 919-945.

A24. Yeşilyaprak, B. (2009). Thedevelopment of thefield of psychologicalcounselingandguidance in Turkey: Recentadvancesandfutureprospects. Ankara University, Journal of Faculty of EducationalSciences, 42(1), 193-213.

A25. Yıldız, A.D.,\& Türk, E.G. Okul psikolojik danışmanlarının görev sınırları ve sorumluluklarının metaforlar ile analizi. Kastamonu Üniversitesi Kastamonu Ë̈itim Dergisi, 99(99), 1-18. 